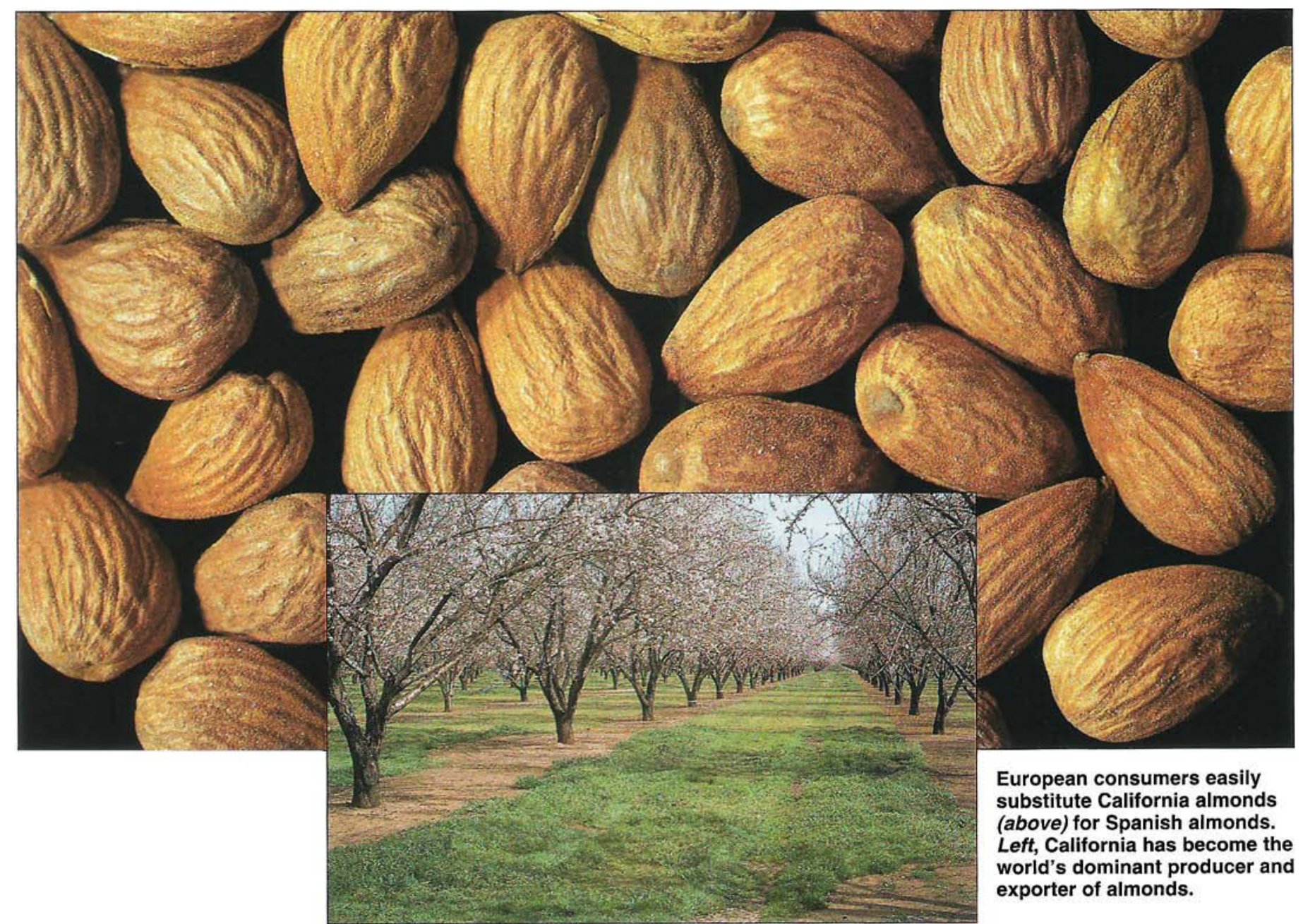

\title{
Restricting flow of almonds to export markets may raise profits
}

Julian M. Alston

$\square$
Jason Christian

$\square$

\author{
Juan R. Murua
}

$\square$

Richard J. Sexton

\begin{abstract}
California is the world's dominant producer of almonds. Statistical models of demand for almonds in the United States and six leading export markets suggest that California can raise revenues and profits in the short run by restricting sales to major export markets. However, in the long run, Spain or other producers may offset those short-run gains by increasing production.
\end{abstract}

Over the past 25 years, California has become the world's dominant almond producer and exporter. California almond production grew from less than 45,000 tons (kernel weight) in 1965 to over 230,000 tons in 1991, with a farm value of $\$ 541$ million. The Golden State now supplies upwards of $85 \%$ of the world almond trade.

Along with increased world production, the almond industry has experienced changing demand relationships. California's rapid rise in the almond export market has been accompanied by Italy's decline. Formerly the world's largest almond exporter, Italy is now often a net importer of almonds. The other major exporter, Spain, has increased almond production (fig. 1), but its exports have changed little.

Although the United States remains the largest single market for California almonds - U.S. consumption has grown steadily from 37,500 tons annually in the early 1970 s to well over 100,000 tons currently - foreign markets, as a group, have grown faster than the domestic market. Some $60 \%$ of the 1991-92 crop was sold on the export market. 


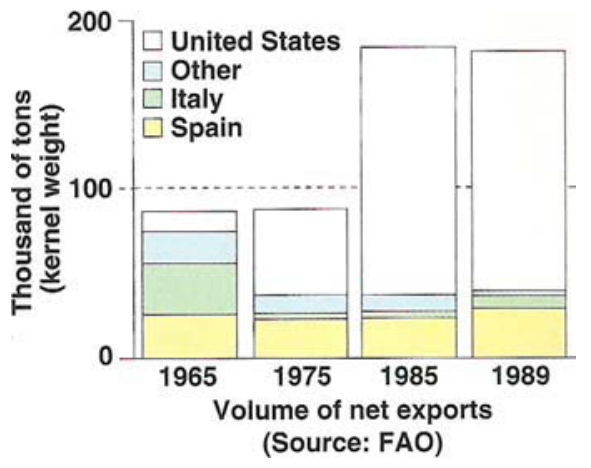

Fig.1 World almond supplies, by producing countries, 1965-89.

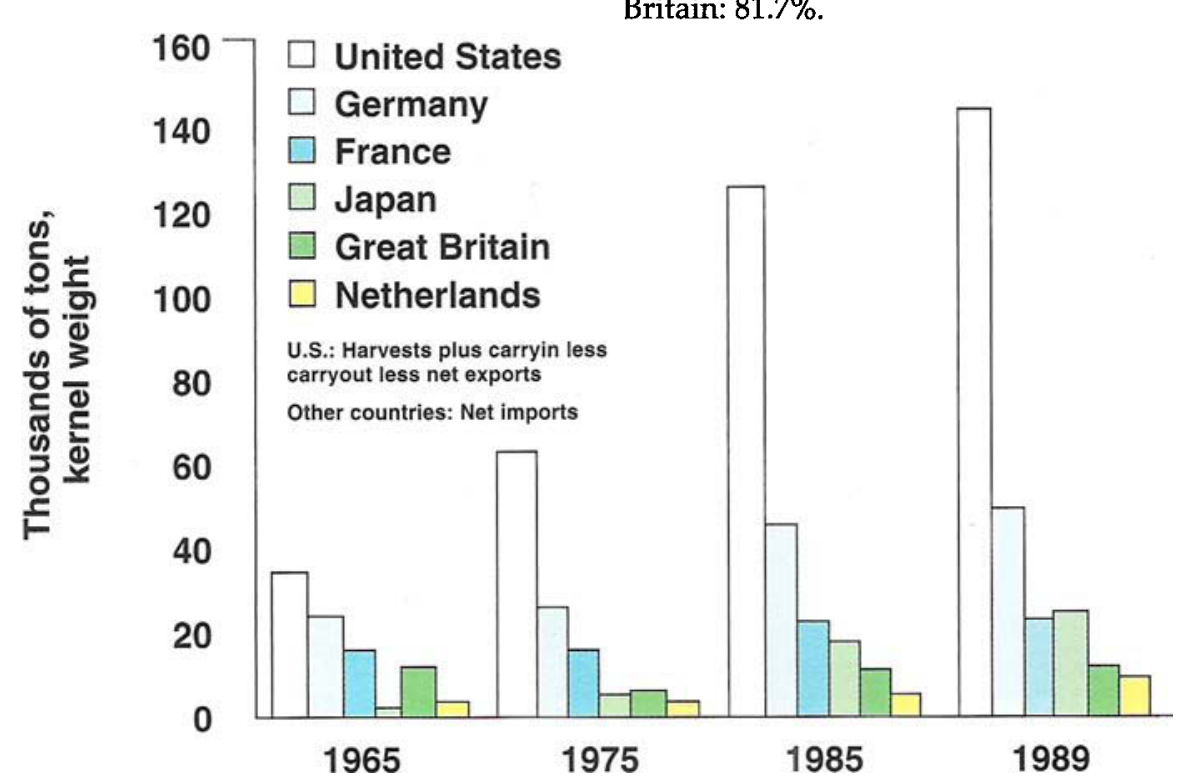

Fig.2 Almond consumption by major almond consuming countries. Sources: Food \& Agriculture Organization, Almond Board of California.

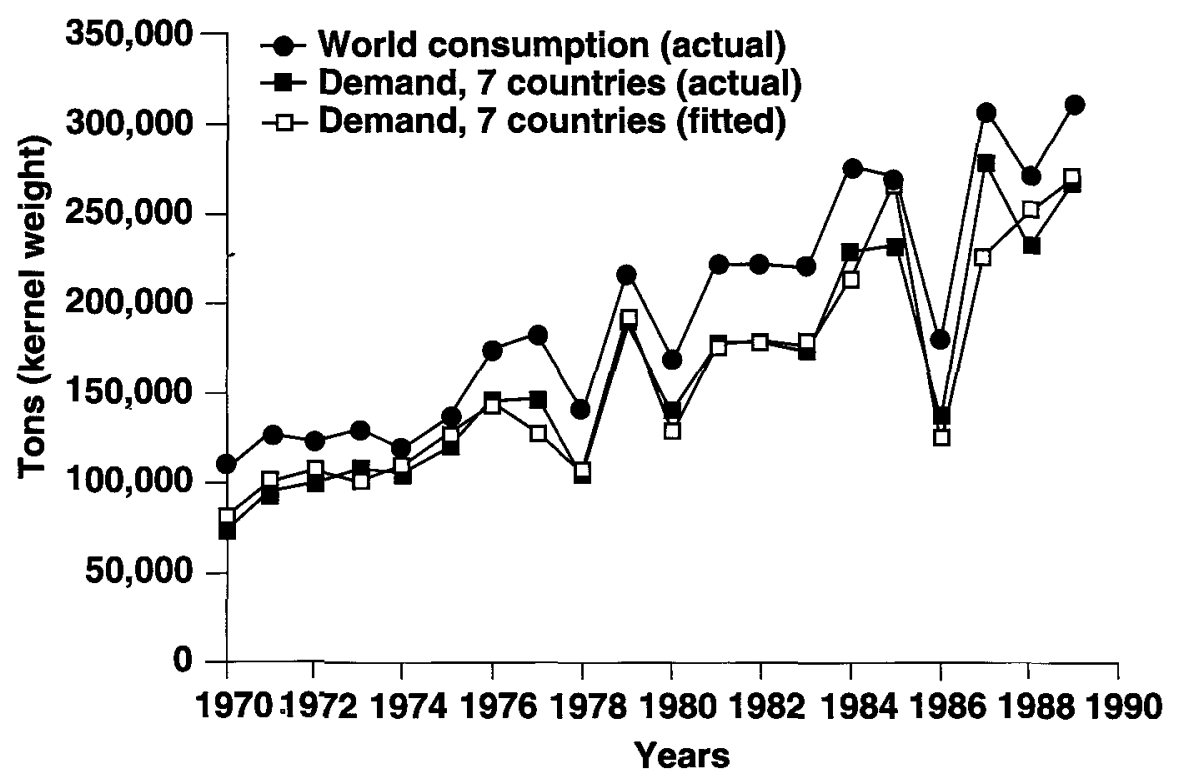

Fig.3 World almond consumption; actual and fitted values from the 7-country model.
Marketing of California almonds is regulated under a federal marketing order. This order provides authority for the Almond Board of California, an industrywide organization comprised of growers and handlers, to regulate the flow of almonds to domestic and export markets. Decisions made by the California almond industry have a major impact on almond prices in other countries, and understanding the relationship between prices and the flow of almonds to the various markets helps it to manage wisely its strong position in the world market.

Our study estimates the relationships between the consumption of almonds and almond prices, prices of substitute commodities, and consumers' incomes in the United States, Japan and the five major European almond-consuming countries. The consumption of almonds from all sources in these countries over the past 25 years is shown in figure 2 . Our study extends prior work on almond demand. Alston and Sexton (California Agriculture, July-August 1991) analyzed a single, aggregate demand function for U.S. almonds using recent data. Bushnell and King (Giannini Foundation Research Report No. 334, Sept. 1986) studied almond demand in individual countries as well as in total, but they analyzed data only through 1980 and thus were unable to investigate important recent developments in the industry.

\section{Price and quantity}

The most important factor influencing purchases of a product such as almonds is price. Knowledge of the pricequantity relationship is crucial because it permits individual firms or an industrywide organization like the Almond Board to identify return-enhancing prices or quantities placed on the market. The relationship between price charged and quantity sold is quantified as the price elasticity of demand, which

\begin{tabular}{|c|c|c|c|}
\hline Price levels & Spain & Italy & United States \\
\hline $\begin{array}{l}\text { Spain } \\
\text { Italy } \\
\text { United States } \\
\text { log price } \\
\text { differences }\end{array}$ & $\begin{array}{l}1.0 \\
0.991 \\
0.959\end{array}$ & $\begin{array}{l}1.0 \\
0.936\end{array}$ & 1.0 \\
\hline $\begin{array}{l}\text { Spain } \\
\text { Italy } \\
\text { United States }\end{array}$ & $\begin{array}{l}1.0 \\
0.920 \\
0.848\end{array}$ & $\begin{array}{l}1.0 \\
0.836\end{array}$ & 1.0 \\
\hline
\end{tabular}


measures the percentage of change in sales due to a $1 \%$ change in price. If demand is very elastic, sales will be significantly affected by a small change in price. An inelastic demand changes only a little when prices change.

The price elasticity of demand is a critical component of a successful almond marketing strategy because the revenue impact of withholding almonds from the market hinges upon the price response. If prices rise by more than $1 \%$ in response to a $1 \%$ decrease in quantity, grower revenues will rise.

\section{Demand and substitute products}

Another factor affecting almond demand is consumers' incomes. For most goods, people buy more as their incomes increase. Our analysis reveals that this general rule of thumb also holds for almonds.

The prices and quantities of substitute goods also affect demand for a product. If almond prices rise, consumers may substitute filberts (hazelnuts) for almonds.

Despite California's large share of the world almond trade, it still faces important competition in export markets, most notably from Spain. The presence of foreign competitors means that a given country does not depend solely on California almond producers for its supply. Rather, California fills the demand that remains after taking account of foreign supplies. This residual demand is derived by subtracting the volume of outside supply from total almond demand.

To assess just how readily consumers will substitute other products for U.S. almonds, we calculated the correlation coefficents between the average export prices of Italian, Spanish and U.S. almonds between 1961 and 1989. Table 1 shows that these correlations are very high. Correlation coefficients range from -1.0 to 1.0. A coefficient close to 1.0 shows that the two prices are closely related - a change in one is usually matched by a change in the other.

The top portion of the table provides correlations among the prices; the bottom portion contains correlations in the logarithms of those variables (roughly equivalent to percentage changes), a more stringent test.

The very high correlation between prices earned by U.S., Spanish and Italian almonds suggests that they are close substitutes and are considered essentially the same. To illustrate this point, suppose a disruption in the supply of Spanish almonds drives up the Spanish price, if Spanish and U.S. almonds were poor substitutes, the rise in the Spanish price would have little effect on the price for U.S. almonds. Table 1 indicates that this scenario does not occur. For this reason we did not distinguish between U.S., Spanish, or Italian almonds when we set up our statistical models to assess demand for almonds in each of the major consuming countries. Rather, we estimated total almond demand in each of the major consuming countries. To apply this estimated total demand to California, we can derive the residual demand for California almonds by adjusting total demand for the California share in each market.

\section{Demand analysis}

In our statistical models to measure almond demand in each of the major consuming countries, we assumed that

\begin{tabular}{|c|c|c|c|c|c|}
\hline Country & $\begin{array}{l}\text { Price elasticity: } \\
\text { total demand } \\
\text { (1) }\end{array}$ & $\begin{array}{l}\text { Price elasticity: } \\
\text { residual demand } \\
\text { (2) }\end{array}$ & $\begin{array}{l}\text { Income } \\
\text { elasticity } \\
\text { (3) }\end{array}$ & $\begin{array}{l}\text { Cross product } \\
\text { effect }^{*} \\
\text { (4) }\end{array}$ & $\begin{array}{l}\text { Adj } \\
R^{2} \\
(5)\end{array}$ \\
\hline U.S. & $\begin{array}{l}-1.076 \\
(6.31) \dagger\end{array}$ & -1.076 & $\begin{array}{c}0.999 \\
(3.30)\end{array}$ & & 0.90 \\
\hline Germany & $\begin{array}{l}-0.487 \\
(4.36)\end{array}$ & -0.700 & $\begin{array}{l}1.316 \\
(6.92)\end{array}$ & $\begin{array}{c}0.252 \\
(3.32)\end{array}$ & 0.95 \\
\hline Netherlands & $\begin{array}{l}-0.622 \\
(7.14)\end{array}$ & -1.095 & $\begin{array}{c}0.338 \\
(2.27)\end{array}$ & $\begin{array}{c}0.356 \\
(2.45)\end{array}$ & 0.88 \\
\hline France & $\begin{array}{l}-0.406 \\
(4.77)\end{array}$ & -0.694 & $\begin{array}{r}0.290 \\
(1.86)\end{array}$ & $\begin{array}{c}0.153 \\
(1.82)\end{array}$ & 0.87 \\
\hline G. Britain & $\begin{array}{l}-0.523 \\
(4.93)\end{array}$ & -0.640 & $\begin{array}{c}0.152 \\
(0.65)\end{array}$ & & 0.75 \\
\hline Italy & $\begin{array}{l}-0.184 \\
(0.49)\end{array}$ & -0.716 & $\begin{array}{l}2.053 \\
(3.58)\end{array}$ & $\begin{array}{l}-2.147 \\
(3.19)\end{array}$ & 0.85 \\
\hline Japan & $\begin{array}{l}-0.431 \\
(2.72)\end{array}$ & -0.431 & $\begin{array}{c}1.849 \\
(8.12)\end{array}$ & & 0.96 \\
\hline
\end{tabular}

per capita consumption of almonds in each country was a function of four factors: (1) the price of almonds in that country, (2) the prices of competing nuts, (3) income in the country as measured by per capita consumption expenditures and (4) the prices of producer or consumer goods that affect demand for almonds, as measured by the country's consumer price index (CPI).

For statistical purposes, all monetary variables were deflated by the appropriate CPI. We investigated a variety of functional forms for the demand relationships. In all cases, the double log specification fit best, so we are reporting results for that model. In double log models, all variables are converted to natural logarithms and a linear relationship among the variables in log form is specified. The double log model provided a direct measure of percentage (elasticity) relationships between almond consumption and explanatory variables such as prices and income. Depending upon data availability, all models were estimated using annual data for either 1961-89 (U.S., the Netherlands, Italy and Japan) or 1970-89 (Germany, France and Great Britain). The results of the demand analysis are summarized by country in table 2 .

The adjusted $\mathrm{R}^{2}$ column reports the percentage of the variation in each country's almond demand over the period of the analysis that is explained by the statistical model. This percentage varies from $75 \%$ for Great Britain to $96 \%$ for Japan.

Note that the price elasticities of total demand are all negative and, with the exception of the United States, less than 1.0 in absolute value. This means that in all major countries to which California exports almonds, total demand is inelastic. In other words, a given percentage increase in price induces a correspondingly smaller reduction in sales. This key result held in general across alternative specifications of the statistical model.

However, in the European countries, California does not fulfill the total demand for almonds but, rather, the residual demand that remains after taking account of Spanish supply. Column 2 contains estimates of the residual demand elasticities. (We computed these elasticities by multiplying the total demand elasticity by the reciprocal of the U.S. market share in each country. Our calculation assumes that Spanish supply is unresponsive to price in the short term.) For the United States and Japan, where California supplies the entire market, the two price elasticities are identical. 
The California almond industry, operating through the Almond Board, affects the almond market by regulating the quantity of almonds on the market, which in turn, influences price. Our analysis of residual demand elasticity implies that a given percentage decrease in the volume of almonds placed on the market will induce a correspondingly greater increase in price in all major consuming countries except the United States and the Netherlands. Decreasing sales by withholding almonds from these markets will increase grower revenues because price rises proportionally higher than quantity falls.

Potentially important in terms of the Almond Board's marketing strategy is the indication that demand for almonds in the United States appears to be more elastic (sales respond relatively more to a price change) than demand in our major export markets. Usually export markets have a more elastic demand than domestic markets. The implication of this finding is that the California industry should consider allocating a greater proportion of its almonds domestically and restricting the amount of almonds for the export markets.

Eventually, however, higher prices and revenues triggered from improved marketing strategies can be expected to trigger increased plantings of almonds and consequently greater supplies, not only from California but also from competitors such as Spain. Although new California supplies would come under the authority of the Almond Board, the same is obviously not true for competitor supplies. A competitor such as Spain can free ride on California's supply management activities. This long-run response to increased profitability of almond production is difficult to measure, but it could offset short-run profits and the industry's decision makers should consider that risk when evaluating market control strategies.

The estimated income elasticities (column 3) are all positive, confirming that as consumers' purchasing power increases they buy more almonds. The estimated magnitude of the income effect, however, differs rather widely among countries, ranging from a high near 2.0 for Japan and Italy to a low of 0.15 for Great Britain. In part, these differences may reflect the different uses to which almonds are put in the various countries. They may also indicate that our income variables are in some cases picking up the effect of other, unmeasured variables that influence almond demand.

Our analysis revealed a distinction between the European almond markets

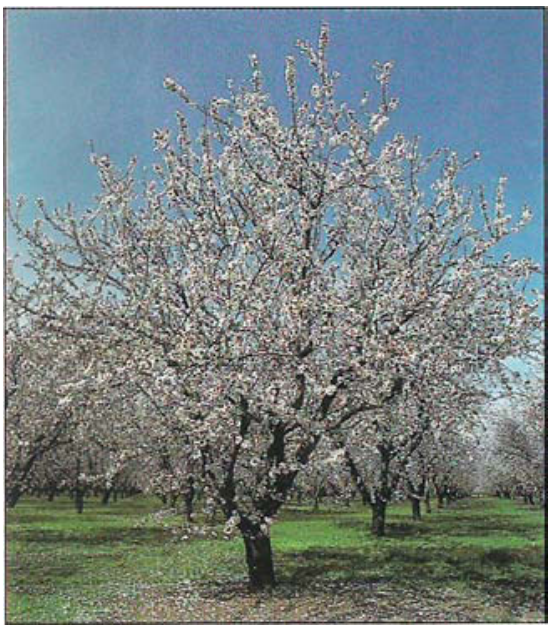

and almond markets elsewhere concerning the importance of substitute nuts. Filbert prices were found to be the only nut prices to significantly affect almond demand, and even the filbert effect was found only in Germany, France and the Netherlands. The European confectionery industry can replace almonds with filberts in many of its processes. In contrast, in the United States, Japan, and Great Britain, our analysis suggests there are no good almond substitutes. This outcome is probably related to the fact that almonds are more often used as a snack food in these markets and as a recognizable stand-alone ingredient, such as slivered almonds in cereals and on cakes, rather than as a ground-up, processed ingredient for marzipan and other confections.

The numbers reported in column 4 measure the response of almond sales to a $1 \%$ increase in the filbert price. For example, we estimated that a $1 \%$ increase in filbert prices in Germany would induce about a $0.25 \%$ increase in almond sales because, for example, food processors would replace some filberts in their recipes with almonds

In our estimate of Italian almond import demand, the cross product effect refers to the Italian almond harvest. The result indicates, not surprisingly, that as the Italian harvest increases, imports of almonds into Italy decreases. The magnitude of the estimated effect suggests a $2 \%$ decrease in imports for each $1 \%$ increase in the Italian harvest. Translating this percentage effect into physical quantities indicates that a 1 ton reduction in the Italian harvest results in an increase in almond imports of about a half ton.

Together the models presented in this report form a quite accurate representation of the bulk of the world demand for almonds. The seven countries included here account annually for between $70 \%$ and $90 \%$ of the world's almond demand. A goodness-of-fit coefficient calculated between actual demands in these countries and their fitted values from our sta- tistical models for 1970-89 indicated that our models captured $97.9 \%$ of the variation in almond demand over this period. Figure 3 plots the full volume of world consumption of almonds over this period, with actual demand and with predicted demand from our statistical models for the seven major consuming countries.

\section{Conclusions}

The results from our study offer several important implications for marketing California almonds:

Inelastic demand for California almonds in export markets suggests that the industry can raise prices and profits in the short run by restricting the flow of almonds to these markets. Short-run gains from pursuing this strategy may be offset in the long run by a loss in market share if competing producers, such as Spain, increase their production in response to higher almond prices.

Where resale of almonds among countries is not easy, price elasticity of demand differences among consuming countries can be exploited by restricting flows of almonds to countries with less elastic demands. The most direct way to implement this type of price discrimination strategy is to restrict sales to the European market. However, because Spain is a major competitor to California in the European market, this strategy will also encourage expansion of the Spanish almond industry.

Promotional campaigns for California almonds in general need not focus on positioning almonds relative to other nut products, because these nuts do not appear to be good substitutes for almonds.

Spanish almonds substitute closely for California almonds in several key European markets. Thus changes in Spanish almond production have an important impact on the California industry. It may be wise for California to invest resources to better monitor the Spanish industry and develop early and accurate forecasts of the Spanish crop.

Julian M. Alston and Richard J. Sexton are Associate Professors, and Jason Christian is Visiting Post-Doctoral Scholar in the Department of Agricultural Economics, UC Davis. Juan R. Murua is former Visiting Post-Doctoral Scholar, Department of Agricultural Economics, UC Davis, and currently Economist with Servicio De Investigacion Agraria, Diputacion General De Aragon, Zaragoza, Spain.

The authors are grateful to Hoy Carman for contributions to this project and insightful comments on this manuscript. 